\title{
Tools for sustainable development: a comparison of building performance simulation packages
}

\author{
S. Hoque ${ }^{1} \&$ A. Sharma ${ }^{2}$ \\ ${ }^{1}$ Department of Natural Resources Conservation, \\ University of Massachusetts, USA \\ ${ }^{2}$ Department of Art, Architecture and Art History, \\ University of Massachusetts, USA
}

\begin{abstract}
The paper evaluates the energy performance of a test case (a single family home) using three different simulation software packages - REM Design, Energy Gauge and Treat. It will discuss the results of each simulation run and the reasons for variations in the results. The inputs for each of the three different simulation tools are heating, cooling, and water heating loads, building shell (exterior walls, roof, foundation, windows, doors) features, air leakage and electric consumption (lighting and appliances). The paper will also highlight the differences in data input for all three software and will underscore areas where improvements to the capabilities offered by the tools and the entities used to define simulation models can be made.
\end{abstract}

Keywords: energy, performance, building, simulation, costs, efficiency.

\section{Sustainable development and energy modelling}

More than one-third of the world's energy consumption is attributed to the construction and building industry [1]. Given the current global energy crisis, there is a critical need to design and construct buildings that are more sustainable. Sustainable buildings minimize building resource consumption, operations and life cycle costs, and improve occupant health and comfort [2]. Energy modelling is used to study the energy performance aspects of a building like heating, cooling, lighting, solar shading, renewable energy, etc. It is a 
proactive approach to evaluating how a building will perform and what effect it will have on its surrounding environment, resources and people. Even a slight modification in a building's design and can have a noticeable effect of a building's energy performance. Energy modelling provides a quantitative understanding about the benefits of energy improvements.

\section{Purpose of energy simulation software}

Energy simulation software packages are used for energy modelling of buildings. They are a tool for calculating and assessing the energy usage throughout the building. Currently they are used to predict and test the energy performance of an existing building or to evaluate whether the proposed design of a new building will meet set standards, guidelines, or norms. They may also assist in performance optimization, to make a building more energy efficient, and calculate cost effectiveness and paybacks for various energy conservation strategies. Using energy simulation software might serve as a means to predict savings since they automatically forecast the implications of a certain decisions, like choice of materials, window size and orientation, sizing of heating and cooling equipment etc.

According to LEEDership Ltd. "Energy modelling is not commonly practiced other than for the purpose of meeting the requirements for green building certification. The benefits of good Energy modelling include reduced capital cost of construction as the tendency to oversize equipment and systems is reduced, as well as improved energy efficiency" [3].

In general, energy simulation software may be used at different stages of a building project like conceptual design, schematic design, and design development and construction document [4].

\section{Shortcomings of energy simulation software}

The data and the standards that energy software use is derived from a variety of surveys, data tables, and materials libraries. One disadvantage of this is that they may be too generalized or idealized and thus not accurately represent the actual building. Also due to the complexity of the building, a simulated building may not perform the same way as it has been modelled, and skew the resulting energy performance data. Although energy modelling is used to test the compliance with certain codes, too much reliance on the simulated output and energy performance may result in a negative impact on the budget and energy performance of a building. Good design principles and energy modelling have to have a correct balance when evaluating a building; otherwise the results may be meaningless. For example, in a test case of an existing residence, the energy simulation software estimated the total energy costs to be $\$ 1600$ whereas the actual costs were $\$ 2600$. In an attempt to model it more closely to the actual costs, by changing certain data entries, one or more parameters always changed in the results. For example, in an attempt to match up the costs for lights and 
appliances, the total cost increased but skewed up the heating and the cooling costs for the house.

\section{Test case}

The 'Montague Urban Homestead' is a single family dwelling unit in Montague, Massachusetts built in 2008. It has been collectively designed by Douglas Stevens, Tina Clarke and Brick Corsa and was the winning entry in the Massachusetts 2009 Zero Energy Challenge. It is a high performance $1152 \mathrm{sq} \mathrm{ft}$ single storey detached dwelling and uses photovoltaic, solar thermal devices, and passive solar technologies. The house has a preliminary HERS index of 6 and was awarded LEED Platinum certification. The HERS Index is a scoring system established by the Residential Energy Services Network (RESNET) in which a home built building code standards scores a HERS Index of 100, while a net zero energy home scores a HERS Index of 0 . A lower HERS Index indicates better energy performance in comparison to the energy performance of a HERS Reference Home. Other features include a super insulated and tight building envelope, high performance windows and super efficient appliances. LEED, Leadership in Energy and Environmental Design, is a building rating system which encourages and accelerates global adoption of sustainable green building and development practices. It categorises certain credits and the number of points gained on successful implementation of those credits. A building is said to be platinum rated if it scores a minimum of 52-69 points under this system. The table below lists out the basic characteristics of the Montague house against a typical energy complaint home (figure 1). (Source: http://www.zechallenge.com /StephensClark-update.htm [5].)

\section{Software description}

\subsection{REM Design}

REM Design, developed by AEC (Architectural Energy Corporation), is software that calculates heating, cooling, domestic hot water, lighting and appliance loads, and energy costs based on a description of the home's design and construction features as well as local climate and utility data. It has a friendly user interface and options for detailed as well as simplified inputs. It has been also approved by the US Department of Energy for Weatherization Assistance Programs in all states. The Weatherization Assistance Program enables low-income families to permanently reduce their energy bills by making their homes more energy efficient [6].

\subsection{Energy Gauge}

Energy Gauge was developed by the Florida Solar Energy Center, a partnership with the U.S. Environmental Protection Agency (EPA) [7]. It performs building simulations in accordance to the Florida commercial energy code and can also 


\begin{tabular}{|c|c|c|}
\hline $\begin{array}{c}\text { SPECIFICATIONS AND } \\
\text { ASSUMPTIONS } \\
\end{array}$ & CODE COMPLIANT HOME & MONTAGUE DESIGN \\
\hline \multicolumn{3}{|l|}{ Building Information } \\
\hline Conditioned Area (ft2) & 1152 & 1152 \\
\hline Conditioned Volume (ft3) & 9216 & 9216 \\
\hline Insulated Shell Area (ft2) & 3241 & 3241 \\
\hline Bedrooms & 3 & 3 \\
\hline Housing Type & SF Detached & SF Detached \\
\hline Foundation Type & Slab & Slab \\
\hline \multicolumn{3}{|l|}{$\begin{array}{l}\text { Annual Energy Consumption } \\
\text { MMBtu/yr }\end{array}$} \\
\hline Heating & 23.39 & 4.33 \\
\hline Cooling & 2.94 & 2.35 \\
\hline Water Heating & 20.4 & 0 \\
\hline Lighting \& Appliances & 17.98 & 17.44 \\
\hline Photovoltaics & 0 & -19.24 \\
\hline Total & 64.71 & 4.89 \\
\hline \multicolumn{3}{|l|}{ Insulation } \\
\hline Slab Floors & $\mathrm{R} 30\left(5.28 \mathrm{~K} . \mathrm{m}^{2} / \mathrm{W}\right)$ & $\mathrm{R} 30\left(5.28 \mathrm{~K} . \mathrm{m}^{2} / \mathrm{W}\right)$ \\
\hline Foundation Walls & None & None \\
\hline Frame Floors & None & None \\
\hline Walls & $\mathrm{R} 16\left(2.82 \mathrm{~K} \cdot \mathrm{m}^{2} / \mathrm{W}\right)$ & $\mathrm{R} 42\left(7.4 \mathrm{~K} \cdot \mathrm{m}^{2} / \mathrm{W}\right)$ \\
\hline Ceiling & $\mathrm{R} 30\left(5.28 \mathrm{~K} . \mathrm{m}^{2} / \mathrm{W}\right)$ & R74 (13.03 K.m²/W) \\
\hline Roof & None & None \\
\hline \multicolumn{3}{|l|}{ Windows } \\
\hline U-Value & 0.35 & 0.3 \\
\hline SHGC & 0.65 & 0.68 \\
\hline Window/Wall Ratio & 0.13 & 0.13 \\
\hline \multicolumn{3}{|l|}{ HVAC } \\
\hline \multirow[t]{2}{*}{ Heating } & ASHP & ASHP \\
\hline & $7.7 \mathrm{HSPF}$ & $8.2 \mathrm{HSPF}$ \\
\hline $\mathrm{AC}$ & 13 SEER & 17 SEER \\
\hline \multirow[t]{2}{*}{ Water Heating } & Conventional & Demand \\
\hline & $.59 \mathrm{EF}$ & $.85 \mathrm{EF}$ \\
\hline \multicolumn{3}{|l|}{ Ventilation } \\
\hline Type & None & $\mathrm{HRV}$ \\
\hline Flow Rate & - & $60 \mathrm{cfm}$ \\
\hline Infiltration Rate & 7.81 ACH50 & $5.0 \mathrm{ACH} 50$ \\
\hline \multicolumn{3}{|l|}{ Renewables } \\
\hline Passive Solar & TBD & TBD \\
\hline $\mathrm{PV}$ & None & $4.56 \mathrm{~kW}$ \\
\hline Solar Thermal & None & Hybrid \\
\hline
\end{tabular}

Figure 1: Comparison between a normal code compliant home and the proposed design of the Montague zero energy house.

calculate energy savings, LEED building energy performance and code compliance. It takes advantage of the US Department of Energy's (DOE_2) software to report hourly simulations as well and is used widely by utility 
planners for testing code compliance, home energy rating and tax credit qualification. The software is easy to use but lacks detailed data input options thus making it more generic.

\subsection{TREAT - Targeted Residential Energy Analysis Tools}

TREAT, by Performance Systems and Taitem Engineering, can simulate hourly based calculation unlike a majority of other simulation packages which focus on annual simulations. TREAT can analyze improvements for the building, group these improvements in packages and calculate projected energy savings from individual improvements and improvement packages in Btu and dollars. It can associate the building model with the actual billing statements and provide feedback to optimize the building energy consumption. It has also been approved by US DOE for the Weatherization Assistance Program in all states, and is widely used by the building energy auditors [8].

\section{The process}

The actual energy modelling of the house was done on REM Design by an energy consultant contracted by the utility company for the Massachusetts Zero Energy Challenge. Using the information from the REM Design file and actual data, building models of the Montague Home were created on Energy GaugeUSA and TREAT. The paper will discuss the differences observed among the software packages and their evident pros and cons. It will also compare the results and simulation reports and suggest any improvements that might be made to the software.

\section{Software analysis - pros and cons}

\subsection{REM Design pros}

- Used for $95 \%$ of HERS ratings.

- $\quad$ Simple interface.

- Detailed inputs. Wide specification library, new inputs can be added to the library.

- $\quad$ Enables importing of data from other software.

- Can generate quick analysis prior to the main report.

- $\quad$ Comprehensive reports. 


\subsection{REM Design cons}

- Cannot generate hourly simulations.

- Does not account for passive solar gains.

- HVAC and materials libraries that come with the software are not up to date (most energy consultants build their own systems and components libraries to model buildings more accurately).

- Does not account for energy star rated appliances.

\subsection{Energy Gauge pros}

- $\quad$ Easy interface.

- $\quad$ Provides examples of sample test homes.

- Enables hourly simulations as well as annual simulations.

- Clearly organized into various main and sub categories.

- Includes site and context around the buildings.

- Detailed inputs for appliances, lighting, temperature, etc.

\subsection{Energy Gauge cons}

- Much less detailed for inputs for ceilings, heating, and hot water.

- Insufficient data input tables, which cannot be expanded to accurately model physical building characteristics.

- No rafter spacing for ceilings, walls etc.

\subsection{TREAT pros}

- Interface is clearly organised.

- Enables input of actual billing data.

- Can take into account building inspection data. 
- $\quad$ Enables hourly reports.

- Combines room-by-room HVAC Analysis with Building Envelope Analysis.

\subsection{TREAT cons}

- Infiltration inputs not sufficient.

- $\quad$ Lighting inputs insufficient.

- Data input tabs are not user friendly and create confusion.

- No input options for renewable energy-photovoltaics. Note: these will be available in the next version of TREAT.

- Insufficient library for ceilings, slabs, walls-problems faced during selecting the type of insulation, rafter spacing with the correct material used [9].

\section{Simulation results}

The simulation results of a building may vary widely from physical reality from program to program. The primary reasons for variations between programs are data sensitivity and types of inputs available in the software's library. Some software are not updated since the time they were developed and do not include the latest energy efficient materials in their databases, though these libraries can sometimes be updated by software users (as in the case of REM Design). There is a degree of randomness for many inputs of these software; some inputs are assumed by the software itself if sufficient data is not available. These assumed values are averaged from a variety of cases, resulting in unpredictable simulation runs. Figure 2 shows what data inputs were used for each of the three software packages. REM Design inputs were closest to the actual because the energy modelling libraries that were up-to-date and adaptable.

In simulating the Montague Home, many variations were observed for each of the three different software (figure 3). The differences, for the most part, are related to the differences in inputs. REM Design calculated the closest heating and cooling loads when compared to actual consumption. The reason for this is the ability to input the actual and exact data into the program. Looking at Figure 3, the simulated results for heating and cooling REM Design, TREAT and Energy Gauge are comparable.

Comparing the water heating loads for the Montague Home, it was found that TREAT calculations were significantly larger than that of REM Design and Energy Gauge. The reason of a high water heating consumption can be attributed to the fact that TREAT (evaluation/trial version) does not have an option for 
solar thermal systems. In the other two software packages (REM Design and Energy Gauge) there is an option where the water heating system and solar system can be linked. The energy generated from the solar thermal directly applies to water heating or in the end the thermal energy generated is deducted from the annual energy consumption (in terms of cost). In the current version of

\begin{tabular}{|c|c|c|c|c|}
\hline & ORIGINAL & REM DESIGN & ENERGY GAUGE & TREAT \\
\hline LOCATION & & Worchester & Worchester & Worchester \\
\hline \begin{tabular}{|l} 
SLAB \\
INSULATION
\end{tabular} & $\begin{array}{l}\mathrm{R} 30(5.283 \\
\left.\mathrm{K} \cdot \mathrm{m}^{2} / \mathrm{W}\right)\end{array}$ & $\mathrm{R} 30\left(5.283 \mathrm{~K} \cdot \mathrm{m}^{2} / \mathrm{W}\right)$ & $\begin{array}{l}\mathrm{R} 10\left(1.76 \mathrm{~K} \cdot \mathrm{m}^{2} / \mathrm{W}\right) \\
\text { (insulation type and } \\
\text { slab location) }\end{array}$ & \begin{tabular}{|l} 
Asks slab \\
insulation-closest \\
option XPS R31 \\
$\left(5.5 \mathrm{~K} \cdot \mathrm{m}^{2} / \mathrm{W}\right)$ \\
\end{tabular} \\
\hline $\begin{array}{l}\text { ABOVE GRADE } \\
\text { WALLS }\end{array}$ & $\begin{array}{l}\text { R42 (7.4 } \\
\text { K.m²/W), stud } \\
\text { spacing } 24 "\end{array}$ & $\begin{array}{l}\mathrm{R} 42\left(7.4 \mathrm{~K} . \mathrm{m}^{2} / \mathrm{W}\right) \text {, stud } \\
\text { spacing } 24 "\end{array}$ & $\mathrm{R} 42\left(7.4 \mathrm{~K} . \mathrm{m}^{2} / \mathrm{W}\right)$ & $\begin{array}{l}\text { R43 (7.57 } \\
\text { K.m²/W) } \\
\text { Stud spacing } 16 "\end{array}$ \\
\hline WINDOWS & \begin{tabular}{|l} 
Extruded \\
fibreglass frame
\end{tabular} & $\begin{array}{l}\text { Overhang distance from } \\
\text { cill and lintel, \% of } \\
\text { interior shading in } \\
\text { summer and winter, } \\
\text { No frame description }\end{array}$ & \begin{tabular}{|l|} 
Asks no. of panes of \\
glass, type of \\
interior shading, \\
NFRC label, no \\
frame description \\
\end{tabular} & $\begin{array}{l}\text { No. of glass } \\
\text { panes, air spacing, } \\
\text { frame description- } \\
\text { insulated } \\
\text { fibreglass }\end{array}$ \\
\hline DOORS & & $\begin{array}{l}\text { Proper door types- } \\
\text { fibreglass without break }\end{array}$ & $\begin{array}{l}\text { Options- } \\
\text { wood/insulated }\end{array}$ & $\begin{array}{l}\text { Fibreglass or } \\
\text { mineral wood } \\
\text { core with steel } \\
\text { stiffeners, no } \\
\text { thermal break }\end{array}$ \\
\hline CEILING & $\begin{array}{l}\text { R74 ( } 13.03 \\
\left.\text { K.m }{ }^{2} / \mathrm{W}\right)\end{array}$ & $\begin{array}{l}\mathrm{R} 100\left(17.61 \mathrm{~K} . \mathrm{m}^{2} / \mathrm{W}\right) \\
\text { spacing between rafters } \\
24 \text { " }\end{array}$ & $\begin{array}{l}\mathrm{R} 100(17.61 \\
\left.\mathrm{K} \cdot \mathrm{m}^{2} / \mathrm{W}\right)\end{array}$ & $\begin{array}{l}\text { R80 ( } 14.09 \\
\text { K.m²/W) } \\
\text { Spacing between } \\
\text { rafters 24” }\end{array}$ \\
\hline ROOF & $\begin{array}{l}8: 12, \text { no } \\
\text { insulation }\end{array}$ & $\begin{array}{l}\text { No tab for entering roof } \\
\text { data, only ceiling }\end{array}$ & $\begin{array}{l}\text { Asks pitch, } \\
\text { insulation, roofing } \\
\text { configuration and } \\
\text { material }\end{array}$ & $\begin{array}{l}\text { No tab for } \\
\text { entering roof data, } \\
\text { only ceiling }\end{array}$ \\
\hline COOLING & $\begin{array}{l}\text { Same system as } \\
\text { heating }\end{array}$ & Same system as heating & $\begin{array}{l}\text { Does not accept no } \\
\text { cooling, has to be } \\
\text { entered separate, }\end{array}$ & Capacity, load \\
\hline HEATING & & $\begin{array}{l}\text { Set point temp., } \\
\text { performance, HSPF, } \\
\text { capacity }\end{array}$ & $\begin{array}{l}\text { only HSPF and } \\
\text { capacity }\end{array}$ & $\begin{array}{l}\text { only HSPF and } \\
\text { capacity }\end{array}$ \\
\hline INFILTRATION & & $\begin{array}{l}\text { Measurement type-e.g. } \\
\text { blower door test }\end{array}$ & $\begin{array}{l}\text { More complex } \\
\text { entries- types of } \\
\text { blower door tests }\end{array}$ & $\begin{array}{l}\text { Only CFM at } 50 \\
\text { PA }\end{array}$ \\
\hline $\begin{array}{l}\text { WATER } \\
\text { HEATING }\end{array}$ & $\begin{array}{l}\text { Instantaneous } \\
\text { water heater }\end{array}$ & $\begin{array}{l}\text { Instantaneous water } \\
\text { heater, location, energy } \\
\text { factor }\end{array}$ & $\begin{array}{l}\text { Location, capacity, } \\
\text { efficiency, gallons, } \\
\text { insulation }\end{array}$ & $\begin{array}{l}\text { Elaborate inputs, } \\
\text { insulation }\end{array}$ \\
\hline $\begin{array}{l}\text { THERMOSTAT } \\
\text { SCHEDULES } \\
\end{array}$ & & No & $\begin{array}{l}\text { Yes, automatic } \\
\text { feedback used }\end{array}$ & $\begin{array}{l}\text { Yes, automatic } \\
\text { feedback used }\end{array}$ \\
\hline APPLIANCES & & $\begin{array}{l}\text { Oven, refrigerator, } \\
\text { lighting }(\% \text { of pin and } \\
\text { CFL })\end{array}$ & $\begin{array}{l}\text { Automatically } \\
\text { assumes all } \\
\text { appliances }\end{array}$ & $\begin{array}{l}\text { Range-simple, no } \\
\text { energy star } \\
\text { selection }\end{array}$ \\
\hline $\begin{array}{l}\text { SOLAR } \\
\text { SYSTEMS }\end{array}$ & Yes & $\begin{array}{l}\text { Loop, orientation, area, } \\
\text { tilt, volume }\end{array}$ & $\begin{array}{l}\text { Type, area, inverter, } \\
\text { line losses }\end{array}$ & $\begin{array}{l}\text { No inputs } \\
\text { available }\end{array}$ \\
\hline
\end{tabular}

Figure 2: $\quad$ Difference in data inputs. 


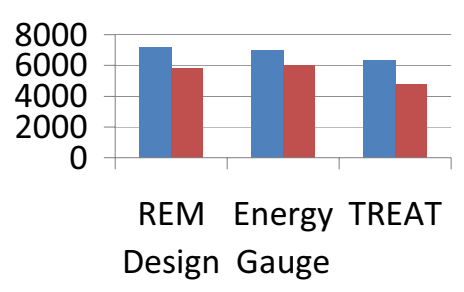

Heating(BTU/hr)

Cooling(BTU/hr)

Figure 3: Comparison of heating and cooling loads.

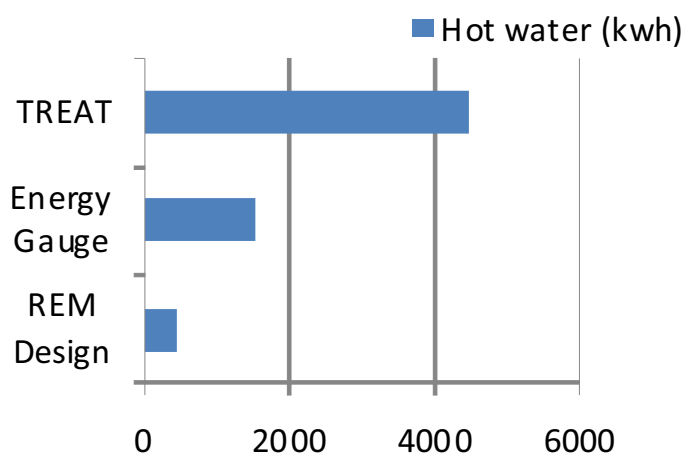

Figure 4: Comparison of hot water consumption.

TREAT renewables and photovoltaics are not accounted for and hence reflect in the comparison (figure 4).

The Montague house uses minimal appliances and lighting. The home is equipped with an energy efficient refrigerator and an electric based oven/cooking range. There is no clothes dryer and washer. Thirty-four percent of the lighting in the house utilizes compact fluorescent bulbs. REM Design and Energy Gauge both apply the percent of CFL while calculating the lighting energy cost. But REM calculates the electricity consumption for lighting and appliances differently than EG and TREAT, suggesting that REM design is more sensitive to inputs for lighting and appliances. One more reason for this variation might be the different assumptions of electricity consumption for the same type of equipment. It can be inferred that REM considers an oven consuming more electricity than what TREAT or EG consider (Figure 5).

The simulation results for PV are dramatically different between REM Design and Energy Gauge. TREAT does not allow for renewable inputs in its current version. REM calculates the input from photovoltaic panels to be worth $\$ 610$ and Energy Gauge calculates it at \$59 (figure 6). REM Design is more capable of parsing a variety of options pertaining to the solar energy, and presents more an accurate model which reflects on the results. 


\section{Lighting \& Appliances (kwh)}

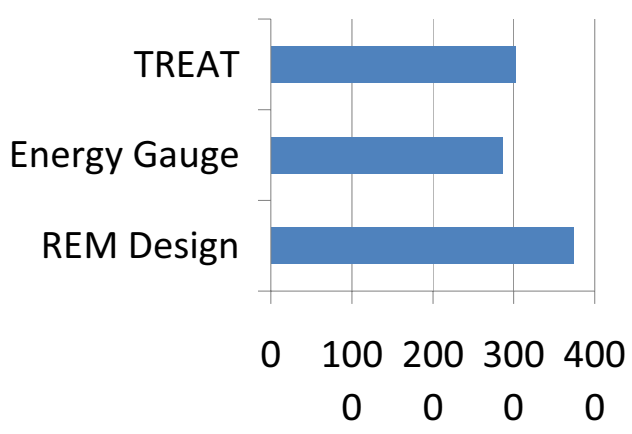

Figure 5: Comparison of energy consumption by lighting and appliances.

Solar Contribution(\$)

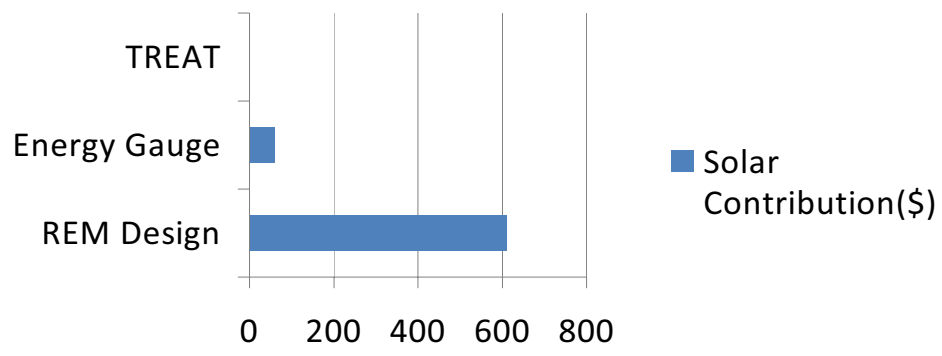

Figure 6: Comparison of photovoltaic inputs.

\section{Conclusion}

Better building design can result in significant reductions in total energy costs, and building simulation has emerged as a means to evaluate and optimize energy demand, health and human comfort, and sustainable practices. Simulation allows energy managers to understand the relationship between design and performance parameters, to identify potential problem areas, and to test design strategies. The three software packages that were compared in this paper are among the most widely used auditing and modelling programs in the United States. They were selected because they represent a majority of the market share in energy management technologies. 


\section{Total Energy Costs (\$)}

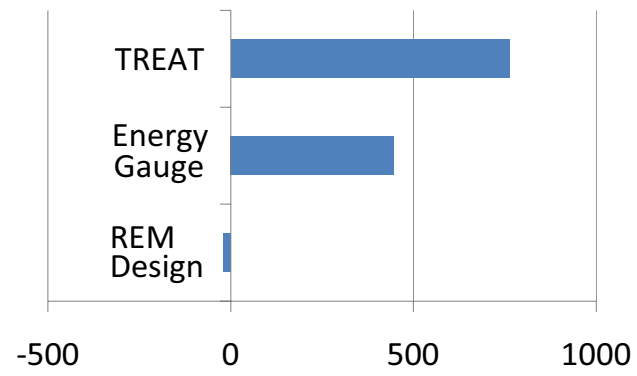

Figure 7: Comparison of total energy consumption as simulated by the three software.

The variations of simulation results by the three software packages can be attributed primarily to the precision of the data input when compared to the actual situation and how and if these inputs can be customized according to the users' requirements. For example, REM Design has libraries which can be edited and customized. Energy Gauge does not allow a user to edit or add to the library. And, TREAT does not allow to input data for renewable energy (TREAT's new version, which is still unreleased will have renewable as an input option). It is important for a user to have a prior knowledge about the abilities and limitations of particular simulation software and to know under what 'category' the building to be modelled will fall. 'Category' refers to the magnitude of energy efficiency of a building. It is also advisable to perform energy modelling at the correct phase during project implementation as it may show certain shortcomings of the proposed design, material choice etc. and allow the building owner/contractor to take corrective actions which would yield a better energy performance in the long run. The variation in inputs due to library limitations is the major reason for the difference in simulated outputs of these software. All software have their merits and shortcomings. For example, REM Design has an excellent modifiable library, on the other hand Energy Gauge seems to be more user friendly, or TREAT takes more detailed inputs and has better capabilities. The major challenge is to identify which software will most suit the proposed building type. It is impossible to establish the optimum level of model accuracy and flexibility in building simulation.

The trade-off between precision and adaptability is itself dynamic and varies according to the modelling task. Ultimately, a model's accuracy can only be assessed by comparing its outputs with the results from the building in use. This study showed that REM Design had the most accurate building model, precisely because it was built with a flexible interface, giving the user a high degree of control over the data inputs and materials tables.

In recent years, building modelling has emerged as a tool to analyze and develop various strategies to reduce energy and resource consumption. However, 
it is not widely used during the design process. This has less to do with technological constraints than with ineffective decision-making. For building performance modelling to become a viable benefit to architects, owners, and contractors, the design process must be integrated with the simulation process. This is necessary in order to identify and include the complex interactions that exist between different components and systems, as well as different end uses of energy. Furthermore, the models must be able to adequately take into account technological changes to the systems or changes to the energy efficiency of such systems. As building simulation tools advance, models will help us to understand not only how to evaluate and optimize energy use within new and existing buildings, but also which strategies and policies are important to help mitigate the effects of unchecked energy use.

\section{References}

[1] Straube, John; Green Building and Sustainability, Building Science Digest 005, 24 October 2006

[2] US Green Building Council, 2009, http://www.usgbc.org

[3] http://www.leedership.com.cn/energymodelling.htm

[4] http://www.buildinggreen.com/features/mr/sim_lit_101_2.cfm, 'Understanding the Energy Modeling Process: Simulation Literacy 101', Marc Rosenbaum, Pittsburg Papers, 2003

[5] http://www.zechallenge.com/StephensClark-update.htm

[6] US, Department of Energy, http://apps1.eere.energy.gov/weatherization

[7] Energy Gauge, http://www.energygauge.com/

[8] TREAT, http://treatsoftware.psdconsulting.com/

[9] Stefentenagel, Adam, Differentiating Energy Modelling Software, Sustainability Built, http://bgbg.org/Content/Documents/Document.ashx? DocId $=37222$ 